\title{
Changing Trends of Consumer Behaviour: A Case on Kerala Rural Market
}

\author{
Dr Avaya Kumar Nayak ${ }^{1}$, Dr Manjusmita Dash ${ }^{2 *}$ \\ ${ }^{1}$ Utkal University, Vanivihar, Bhubaneswar-751004, Orissa, INDIA \\ ${ }^{2}$ Dept of Business Administration, Utkal University, Vanivihar, Bhubaneswar-751004, Orissa, INDIA \\ *Corresponding Authors: Dr Manjusmita Dash, Dept of Business Administration, Utkal University, \\ Vanivihar, Bhubaneswar-751004, Orissa, INDIA
}

\begin{abstract}
Rural markets are gaining importance in emerging economies. 'Go rural' is the marketer's new slogan. Indian marketers as well as multinationals, such as Colgate-Palmolive, Godrej and Hindustan Lever have focused on rural markets. Two-thirds of Indian consumers reside in rural areas and almost half of the national income is comes from there. There indeed is a place for premium products, but consumers in rural market for those products are spread and hard to reach. Therefore, such products can be left to be bought from the adjacent urban centre. The appeal of rural market is in their size as mass markets. Those who plan products for such mass markets will flourish and grow up rapidly. A decade ago, the rural market was more unstructured and was not a prioritized target location for corporates. Gradually, corporates realized that there was saturation, stiff competition and clutter in the urban market and a demand was building up in rural areas. The sale of FMCG products in rural markets is growing at a fast pace, even faster than that in the urban market. The paper describes the development of rural marketing in India which is based on the two villages of Kerala i.e. Alleppy and Kumarakom regarding their buying decision process and relevant factors to influence for overall consumption pattern.
\end{abstract}

Keywords: Rural market, Rural Consumer, Consumer Behaviour, Consumer Attitude, Strategies \& Buying Motives.

\section{INTRODUCTION}

Majority of the population resides in Rural India, But unfortunately majority of the corporate focus only on urban areas. The rural market has been growing steadily over the past few years and is now even bigger than the urban market. About 70 per cent of India's population lives in villages. More than 800 million people live in villages of India. Inspite of this fact, marketers earlier concentrated on the urban markets and scheduled their strategy accordingly. As the competition increased in urban areas, and taking into account the increasing demand for FMCG's in rural areas, the marketers expanded their business in rural areas. Perhaps it has become a policy for their survival. Marketers found different strategies to penetrate in the rural segment. The pioneer corporate was HLL. The Indian FMCG sector is the fourth largest sector in the economy with a total market size in excess of US\$ 13.1 billion. It has a strong MNC presence and is characterized by a well established distribution network, intense competition between the organized and unorganized segments and low operational cost. Availability of key raw materials, cheaper labor costs and presence across the entire value chain gives India a competitive advantage. In fact it has been estimated that the rural markets are growing at five times the rate of urban markets. About $70 \%$ of bicycles, mechanical watches and radios and about $60 \%$ of batteries, sewing machine and table fans are sold in rural India The Fast Moving Consumer Goods (FMCG) sector in rural and semi- urban India is estimated to cross US\$ 100 billion by 2025.

The lustrous and glowing backwaters of Alleppey beckon you to come and explore the untamed wilds and experience the pure thrill of being with water birds, fishermen, the warm sun and unspoilt beauty. Alleppey or Alappuzha in Kerala, South India is known for its labyrinth of backwaters that seem to envelop this tiny Kerala travel destination into a unique water world. Alleppey is a great favorite for those who wish to spend some quiet time with nature and is just the right place to go on backwater cruises. In fact a houseboat cruise on a rice barge on the Alleppey backwaters will open up a serene and remote world resounding with natural sounds covered in an emerald mist. Kumarakom in Kerala is $14 \mathrm{kms}$ away from Kottayam and is one of the most preferred destinations of tourists. The primary 
objective of the study is to Identify the needs of rural customers of these selected areas of Kerala ,the factors influencing their purchasing of product/service from the market to decide the when, where, and how rural consumers want it.

The objectives of the present study are:

1. To understand the rural buying decision process.

2. To understand the factors influencing the purchase of villagers.

\section{MeTHOdOLOGY}

This study is based on the primary data in connection to the above objectives; a survey was conducted with the help of structured questionnaire in two villages of Kerala State. The two villages i.e. Alleppey and Kumarakom of Kerala State. Purposively which are well connected with other villages by Road and Telephone. The villages are selected on the basis of population and other economic factors of development such as 1) Electricity 2) Socio- economic Development. Most of the respondents are financially very sound.

\subsection{Data Collection}

The data was collected with the help of questionnaire from Alleppey and Kumarakom village of Kerala. The sample size is as follows:

From the village Alleppey in all 50 samples were selected. The factor such as age group, sex, income were taken into account. The sex ratio of the respondent is kept equal ( 25 male and 25 female).

\subsection{Analysis of Survey}

The age group of the respondents is presented in Table No. 1.1 which shows that below 20 years there are 5 respondents (10\%). In the age group from 20 to 30 there 10 respondents (20\%) from 30 to 40 there are 10 respondents (20\%) in 40 to 50 age group there are 10 respondents (20\%), in age group 50 to 60 there are 10 respondents $(20 \%)$ and in the age group 61 and above there are 5 respondents. $(10 \%)$.

Table1.1. Age Group of the Respondents

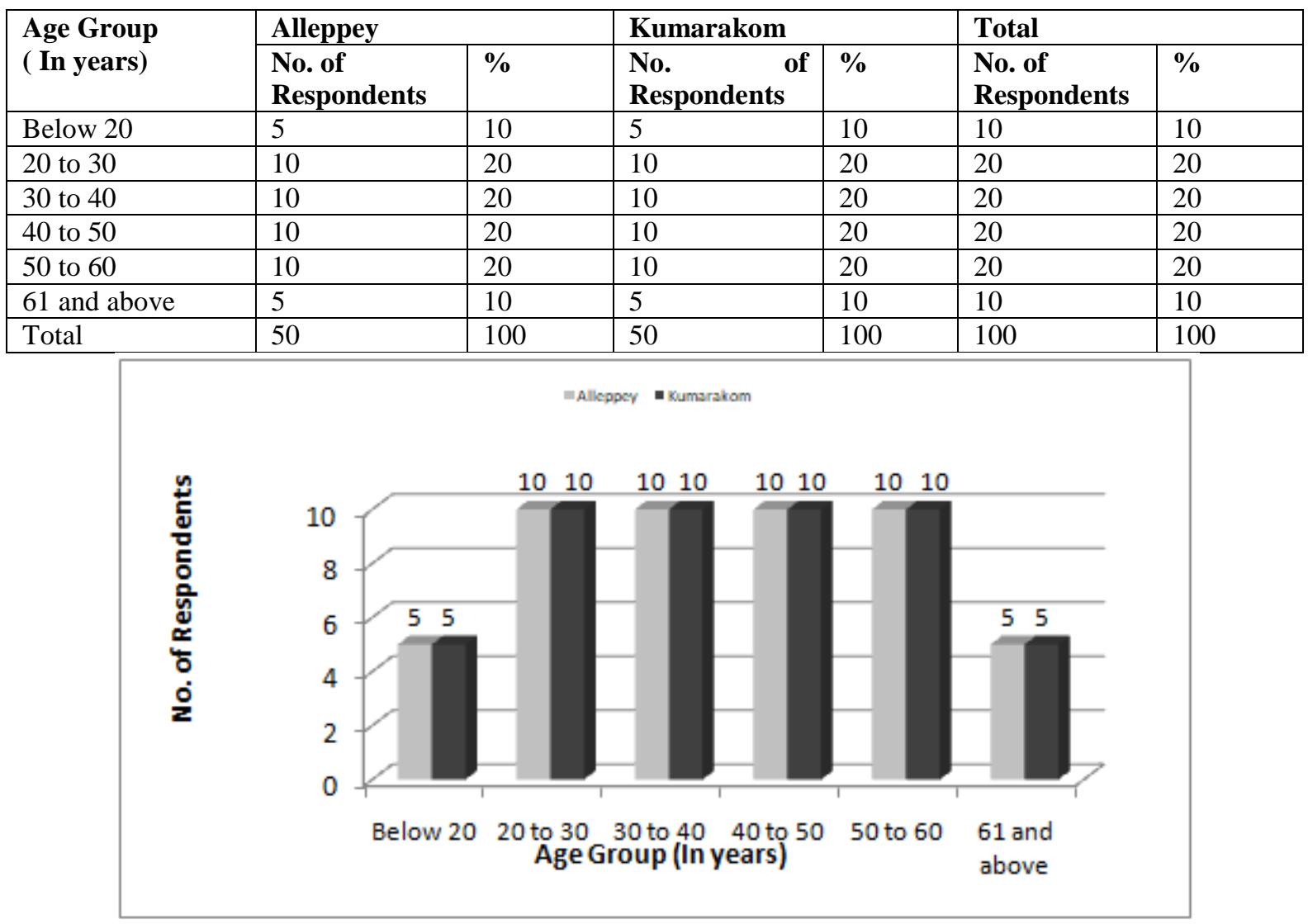

Figure1. Age Group of the Respondents 


\subsection{Sex of the Respondent}

This is changing with the increased number of working wives and the husbands doing more family shopping. In case of expensive products and services, husbands and wives engage in more joint decision-making. The marketer needs to determine which member normally has the greater influence in choosing various products. Sex of the consumer is an important aspect in determining the buying behavior and the source of information he/she acquires. The numbers of the sex are kept equal to identify whether purchase decision differs from sex to sex. (Ref. table 1.2)

Table1.2. Sex of the Respondents

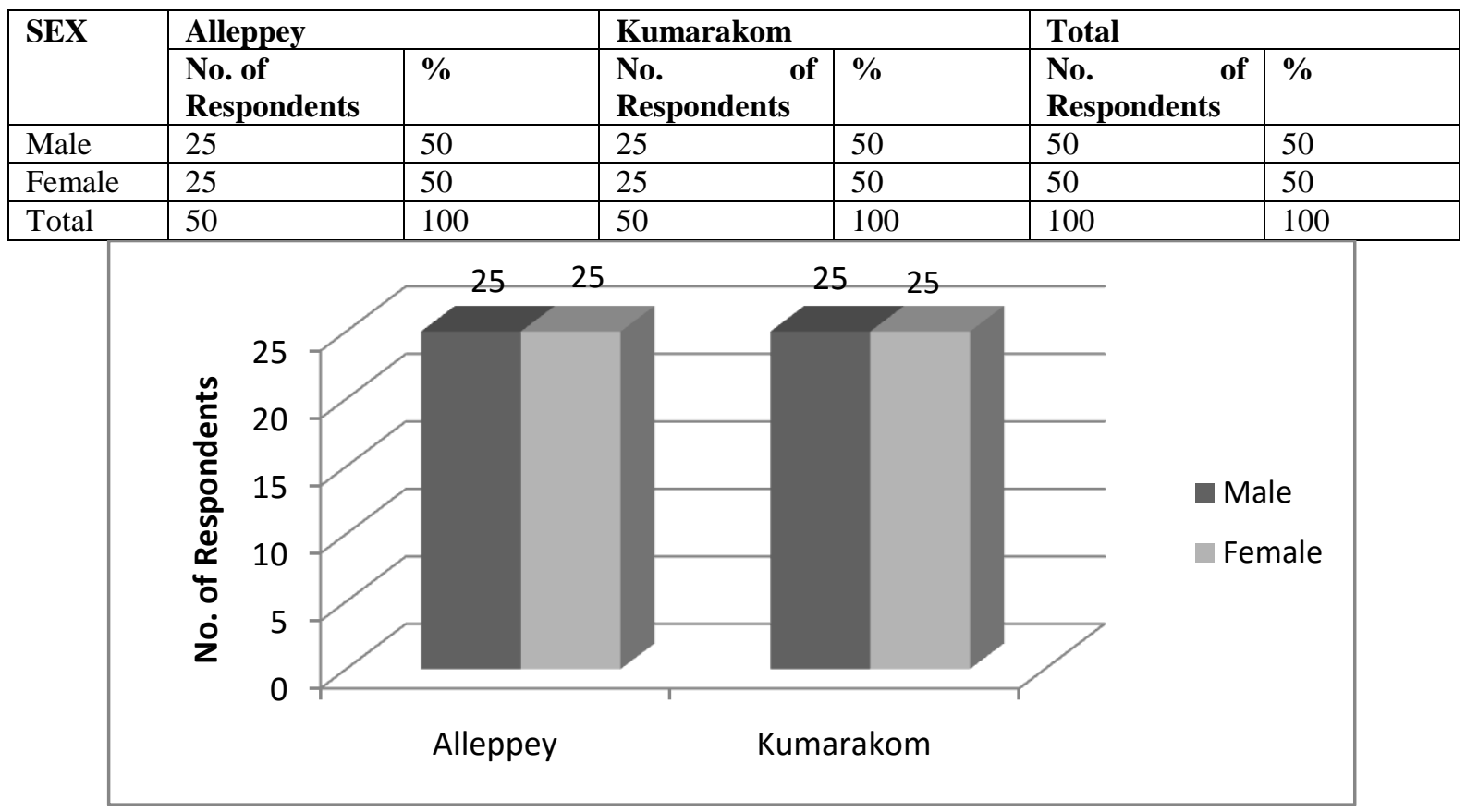

Figure2. Sex of the Respondents

\subsection{Income Group}

The income of the buyer determines the purchasing power. Though a consumer has a need for some product, if he is not backed by income, he cannot purchase that product. Therefore, income plays an important role in buyer behavior The study shows that in Alleppey village 14 respondents (28\%) have income below Rs. 20,000.00, 12 respondents (24\%) are in Rs. 20,000 to 50,000 income group, 8 respondents (16\%) belong to the income group of Rs. 50,000 to $80,000,12$ respondents $(24 \%)$ are in the income group of Rs. 80,000 to 1,00,000 and only 4(8\%) of the respondents are having the income above Rs. 1,00,000.00.

In the village Kumarakom, the income groups existing are 12 respondents (24\%) below Rs. 20,000/-, 12 respondents (24\%) having an income of Rs. 20,000 to 50,000, 10 respondents (20\%) are in the income group of Rs. 50,000 to 80,000, 10 respondents (20\%) are in the income group of Rs. 80,000 to $1,00,000$ and 6 respondents (12\%) are having an income of more than Rs. 1,00,000/-.

The total figures indicates that in the income group of below 20,000 there are 26 respondents $(26 \%)$, in the income group of Rs. 20,000 to 50,000 there are 24 (24\%) respondents, in the income group of Rs. 50,000 to 80,000 there are $18(18 \%)$ respondents, in the income group of Rs. 80,000 to $1,00,000$ there are $22 \%(22 \%)$ respondents and in the income group of Rs. 1,00,000 and above there are only 10 (10\%) respondents (Refer Table 1.3)

Table1.3. Income Group of the Respondents

\begin{tabular}{|l|l|l|l|l|l|l|}
\hline \multirow{2}{*}{$\begin{array}{c}\text { Income Group } \\
\text { (in Rs.) Annual }\end{array}$} & \multicolumn{2}{|l|}{ Alleppey } & Kumarakom & \multicolumn{2}{l|}{ Total } \\
\cline { 2 - 7 } & $\begin{array}{l}\text { No. of } \\
\text { Respondents }\end{array}$ & $\%$ & $\begin{array}{l}\text { No. of } \\
\text { Respondents }\end{array}$ & \% & $\begin{array}{l}\text { No. } \\
\text { Respondents }\end{array}$ & $\%$ \\
\hline Below 20,000 & 14 & 28 & 12 & 24 & 26 & 26 \\
\hline 20,000 to 50,000 & 12 & 24 & 12 & 24 & 24 & 24 \\
\hline 50,000 to 80,000 & 8 & 16 & 10 & 20 & 18 & 18 \\
\hline
\end{tabular}


Changing Trends of Consumer Behaviour: A Case on Kerala Rural Market

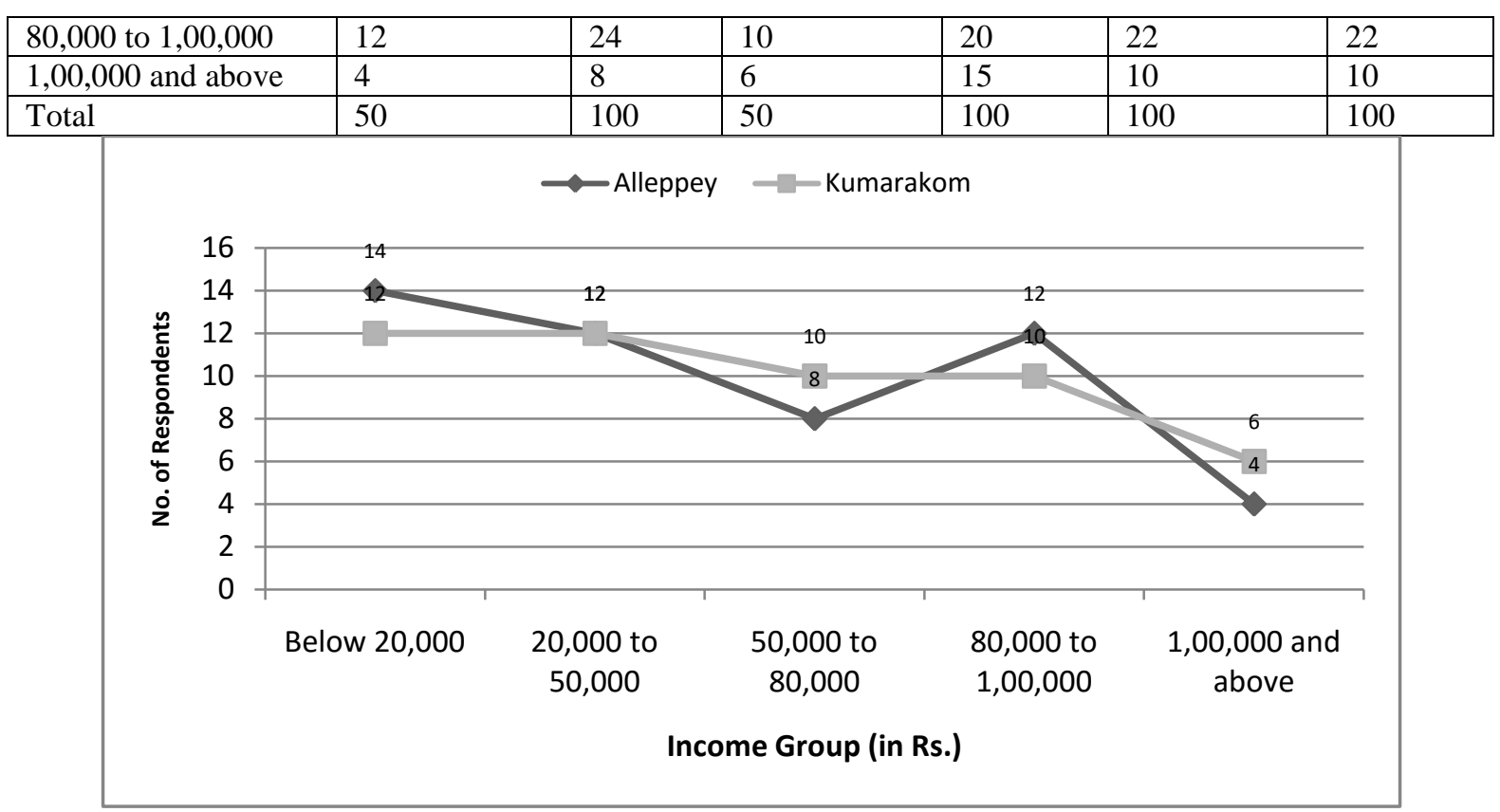

Figure3. Income Group of the Respondents

\subsection{Place of Purchase}

The place from where consumer buys the product is an important aspect. Through this the corporate can design the penetration strategy. It is not only a duty of the Marketer to manufacture the good product, but also a prime duty to make the goods available at the place from where the consumer prefers to buy it. From the study, it is clear that in Alleppey village 12 respondents (24\%) prefer to buy from village shopkeepers, 21 respondents (42\%) prefers to buy from weekly market, 10 respondents (20\%) prefer to buy from Taluka Market. Only 7 respondents (14\%) prefer to buy from district Market. In the village Kumarakom 14 respondents (28\%) prefer to buy from village shopkeepers, 19 respondents (38\%) prefer to buy from weekly market, 9 respondents $918 \%$ ) prefer to buy from Taluka Market and only 8 respondents (16\%) prefer to buy from district market. Put together 26 respondents $(26 \%)$ purchase from village shopkeeper, 40 respondents $(40 \%)$ purchase from weekly market, 19 respondents (19\%) purchase from Taluka Market and 15 respondents (15\%) purchase from the district market. (See Table No. 1.4).

Table1.4. Place of Purchase

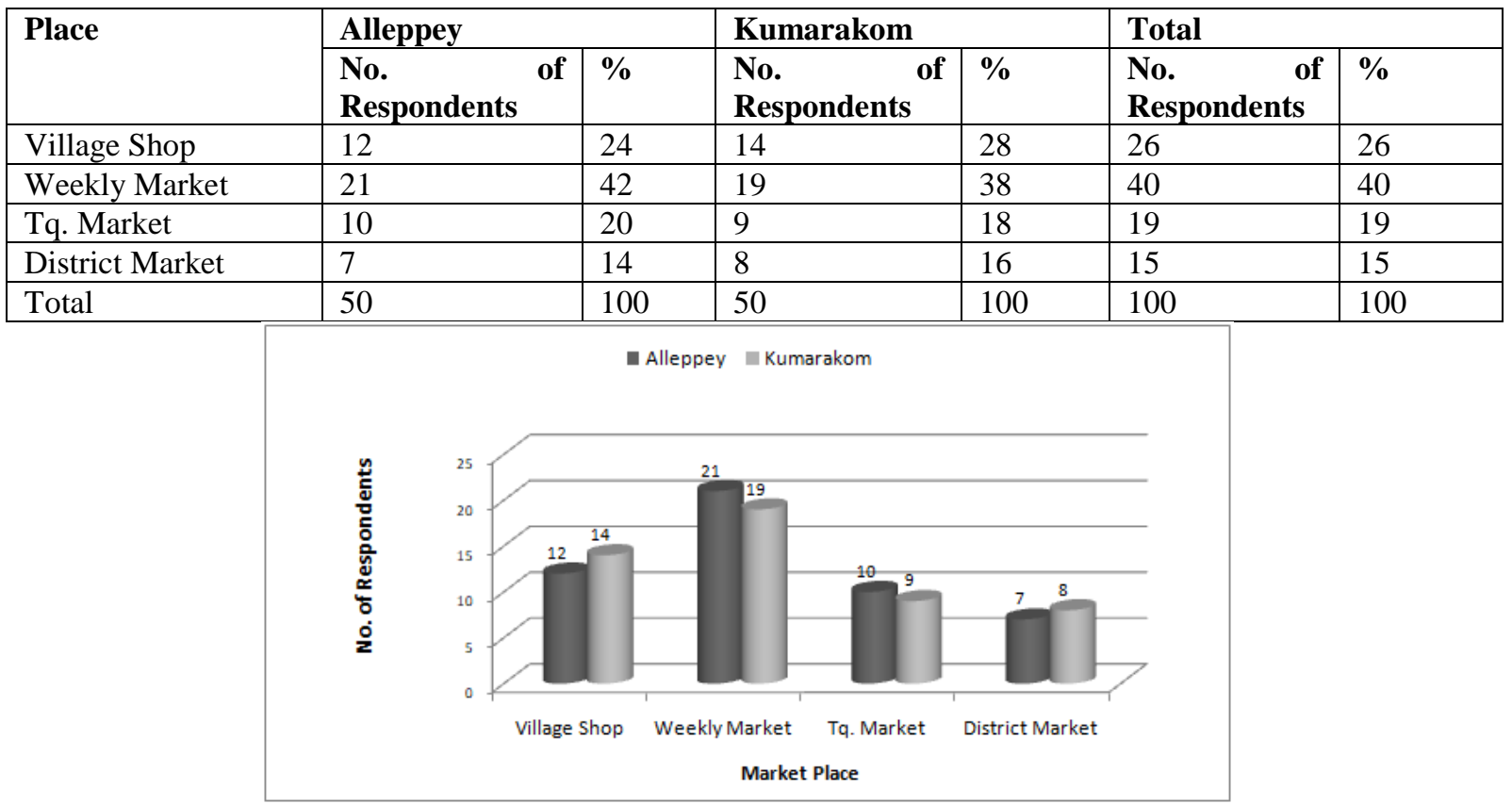

Figure4. Place of Purchase 


\subsection{Factors Affecting Purchase}

From the survey the following facts and figures come ahead regarding the factors considered for purchase, which is shown in Table 1.5. In the village Alleppey 14 respondents (28\%) reported that price factor is taken into account, 10 respondents $(20 \%)$ reported that quality factor is more important for them, 8 respondents (16\%) reported that availability is considered while purchasing, 18 respondents $(36 \%)$ reported that small size is preferred while purchasing. 14 respondents $(28 \%)$ reported that they prefer quality, 10 respondents $(20 \%)$ reported that they purchase according to the availability of the product, 15 respondents (30\%) reported that they take into account small size while purchasing the FMCG Product.

Table1.5. Factors affecting purchases of the Respondents

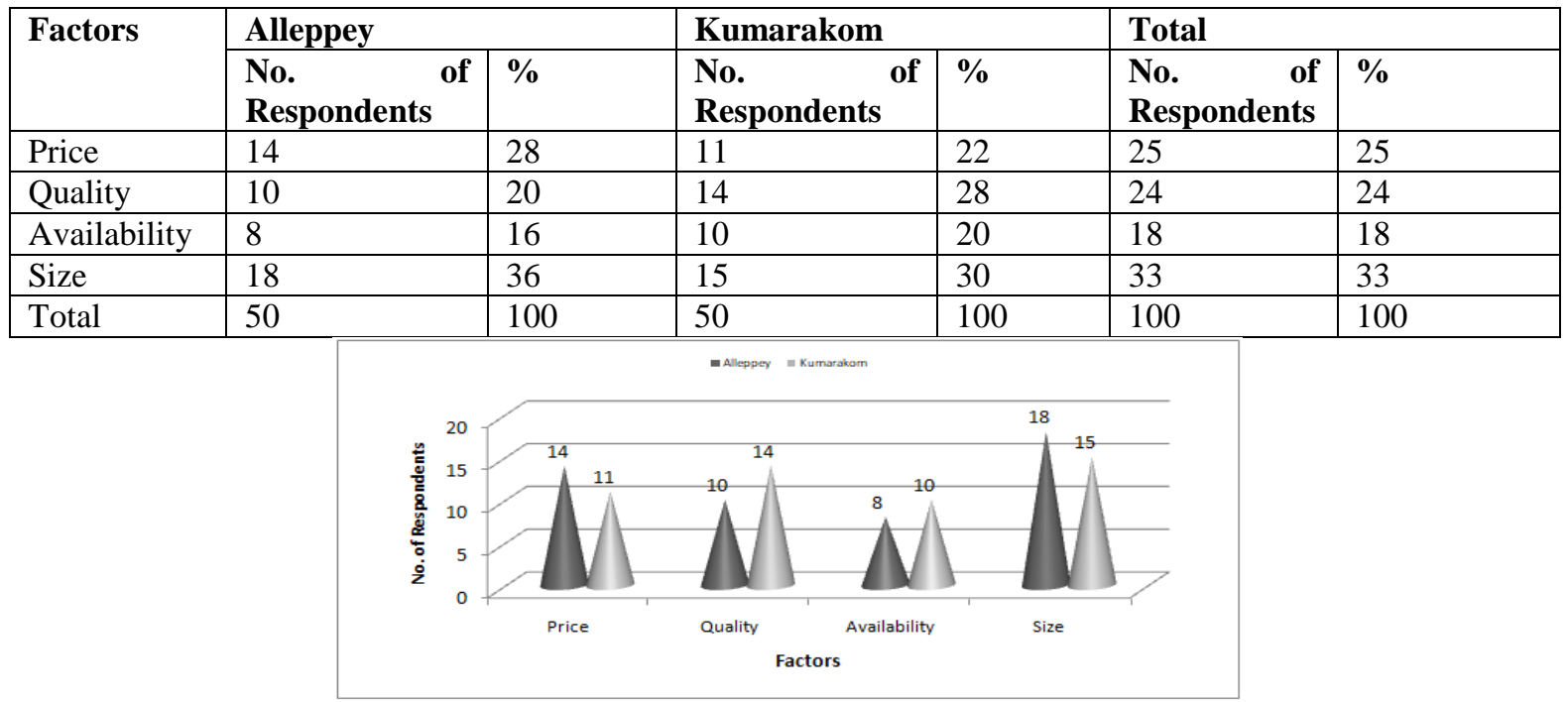

Figure5. Factors affecting purchases of the Respondents

\subsection{Source of Information}

From the fieldwork, it is clear that the rural consumer gets the information from various sources which reflect in their purchase behavior. The same is presented in Table 1.6.

Table1.6. Media reach of the Respondents

\begin{tabular}{|l|l|l|l|l|l|l|}
\hline & \multicolumn{3}{|l|}{ Alleppy } & \multicolumn{2}{l|}{ Kumarakom } & Total \\
\cline { 2 - 8 } Media & $\begin{array}{l}\text { No. of } \\
\text { Respondents }\end{array}$ & \% & $\begin{array}{l}\text { No. of } \\
\text { Respondents }\end{array}$ & \% & $\begin{array}{l}\text { No. of } \\
\text { Respondents }\end{array}$ & \% \\
\hline T.V & 18 & 36 & 15 & 30 & 33 & 33 \\
\hline Radio & 9 & 18 & 7 & 14 & 16 & 16 \\
\hline Newspaper & 4 & 8 & 9 & 18 & 13 & 13 \\
\hline Friends & 7 & 14 & 6 & 12 & 13 & 13 \\
\hline Shopkeepers & 12 & 24 & 13 & 26 & 25 & 25 \\
\hline Total & 50 & 100 & 50 & 100 & 100 & 100 \\
\hline
\end{tabular}

In the village Alleppey 18 respondents (36\%) reported that they get information about the products from T.V, 9 respondents (18\%) reported that radio is the source of information for them, 4 respondents $(8 \%)$ reported that they get information from Newspapers, 7 respondents (14\%) reported that they rely on friends and 12 respondents (24\%) reported that they get information from the shopkeepers.

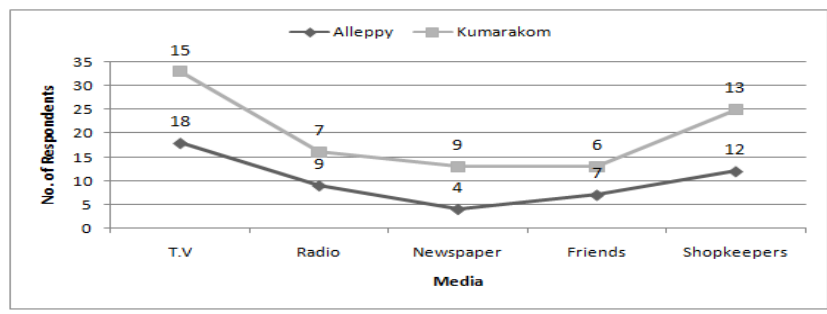

Figure6. Media reach of the Respondents 
In the village Kumarakom 15 respondents (30\%) get information from T.V, 7 respondents (14\%) get information from Radio, 9 respondents (18\%) get information from Newspapers, 6 (12\%) rely on friends for information. 13 respondents $(26 \%)$ get information from shopkeepers. The above information makes it clear that 33 respondents $(33 \%)$ get information from T.V, 16 respondents (16\%) get information from Radio, 13 respondents $(13 \%)$ get information from newspapers, 13 respondents $(13 \%)$ get information from friends and 25 respondents $(25 \%)$ get information from the shopkeepers.

\subsection{Who Takes the Purchase Decision?}

In the survey conducted following facts and figures come out regarding purchase decision which is seen in Table 1.7. It is observed that in Alleppey village 10 respondents (20\%) reported that the purchase decision for FMCG is taken by the earning male of the family, 14 (28\%) reported that the earning female take purchase decisions, 26 (52\%) reported that the decision regarding, purchase of FMCG is taken by youth and children of the family. In the village Kumarakom, 8 respondents (16\%) reported that the earning males take the purchase decision. 12 respondents $(24 \%)$ reported that the purchase decision is taken by the earning female and 30 respondents $(60 \%)$ reported that the youth and children of the family take the decision regarcling purchase of FMCG. Put together in both the village $18(18 \%)$ earning male take buying decision. In case of $26(26 \%)$ decisions are taken by the earning female and 56 (56\%) reported that youth and children take the purchase decision.

Table1.7. Buying Decisions of the Respondents

\begin{tabular}{|c|c|c|c|c|c|c|}
\hline \multirow[t]{2}{*}{ Buying Decision } & \multicolumn{2}{|l|}{ Alleppey } & \multicolumn{2}{|l|}{ Kumarakom } & \multicolumn{2}{|l|}{ Total } \\
\hline & $\begin{array}{l}\text { No. of } \\
\text { Respondents }\end{array}$ & $\%$ & $\begin{array}{l}\text { No. of } \\
\text { Respondents }\end{array}$ & $\%$ & $\begin{array}{l}\text { No. of } \\
\text { Respondents }\end{array}$ & $\%$ \\
\hline Earning male & 10 & 20 & 8 & 16 & 18 & 18 \\
\hline Earning Female & 14 & 28 & 12 & 24 & 26 & 26 \\
\hline Youth and Children & 26 & 52 & 30 & 60 & 56 & 56 \\
\hline Total & 50 & 100 & 50 & 100 & 100 & 100 \\
\hline & $\begin{array}{l}20 \\
10 \\
0\end{array}$ & male & $\begin{array}{l}\text { Earning Female Youth a } \\
\text { uying Decisions }\end{array}$ & Child & & \\
\hline
\end{tabular}

Figure7. Buying Decisions of the Respondents

\section{OBSERVATIONS}

1. It is observed that T.V. plays a major role in informing the customer about a particular product $(33 \%)$.

2. The shopkeepers also play a major role in informing the customers about the product $(25 \%)$.

3. It is also found that Radio and Newspaper are also a source of information but at very less proportion (13 and $13 \%$ respectively).

4. The observation regarding purchase decision is that the youth and children of the family are very aggressive in decision making for FMCG @ ,56\%.

5. The earning females also take purchase decision in case of $26 \%$.

6. Regarding the purchase factor, it is observed that $33 \%$ of the respondents purchase the product of small size; and $25 \%$ customers are influenced by the price factor.

7. It is also observed that $40 \%$ of the respondents prefer to purchase from weekly market because of the various variety available at a competitive price. Only 15\% of the customers prefer to. buy from District market as they visit the district headquarters frequently far some or the other reason. The customers who' purchase from district market are generally, the customers of upper and middle class. 


\section{SUgGeSTIONS}

$>$ The corporate should consider weekly market as the best option for penetration of FMCG in rural areas.

$>$ They should provide the goods in small size and low price because most of the rural customers are economically backward.

$>$ The media of information such as T.V. should be given more weightage, which reflect- in the purchase decision.

$>$ They should concentrate on youth and children who are observed as a decision maker in rural area.

\section{CONCLUSION}

Majority of sale of FMCG products is made to middle class households and over $50 \%$ of middle class is in rural India. The sector is excited about burgeoning rural population whose incomes are rising and which is willing to spend on goods designed to improve life style. Rural India has more than $70 \%$ population in 6.27 lakh villages, which is a huge market for FMCG product. All the income groups purchase the FMCG product but their brands differ from each-other. The place of purchase, which the rural consumer prefers, is the weekly market, which is a good channel of distribution of FMCGs. Moreover the youth who visits the Taluka place or district place are influenced by the city culture and it is reflected in their purchasing decision. Overall the marketer should understand the customer before taking up the road to the rural market. Also with near saturation and cut throat competition in urban India, many producers of FMCG are driven to give bold new strategies for targeting the rural consumers in a big way. Thus ,looking at the challenges and the opportunities which rural markets offers to the marketers, it can be understood that the future is very promising for those who can understand the dynamics of rural markets and exploit them to their best advantage.

\section{BIBLIOGRAPHY}

[1] Rural Marketing, Ravindranath v. Badi and Narayansa V.Badi, Himalaya Publishing, 2004.

[2] What's Hot Around the Globe: Insights on Growth in Household Products? A Report by AC NIELSEN Consultancy

[3] Strategic Analysis of 3PL Markets in the Indian FMCG Sector-A Report by Frost \& Sullivan Consultancy

[4] Fast Moving Consumer Goods-A Report by India Brand Equity Foundation (IBEF)

[5] The Great Indian Bazaar- A Report by India Brand Equity Foundation (IBEF)

[6] A billion buyers' marketplace- A Report by India Brand Equity Foundation (IBEF)

[7] The Great Indian Market- A Report by National Council of Applied Economic Research (NCAER)

[8] FAST MOVING CONSUMER GOODS- A report by PricewaterhouseCoopers For India Brand Equity Foundation (IBEF)

[9] Pradeep Kashyap and-Siddharatha Raut "The Rural Marketing Book" Biztantra (Dremtech Press), New Delhi pp 83,88 (2006)

[10] Amarchand D and Vardharajan B "an Introduction of Marketing" Vikas publication house Pvt. ltd. Fifth edition pp 69 (1983)

[11] Rajan Sexena "Marketing Management", Tata McGrawHill Publishing. Co-Ltd., New Delhi PP 371 (2000)

[12] Dr. B. Nagaraja, Consumer Behaviour in Rural Areas, Indian Journal of Marketing, PP 30-31 (Nov. 2004)

[13] Dr. W.K. Sarwade, Emerging Dimensions of Buyers Behavious in rural Area, Indian journal of Marketing, PP 13 (Feb, 2002)

Citation: Dr Avaya Kumar Nayak, Dr Manjusmita Dash, "Changing Trends of Consumer Behaviour: A Case on Kerala Rural Market" International Journal of Managerial Studies and Research (IJMSR), vol 9, no. 4, 2021, pp. 01-07. doi: https://doi.org/10.20431/2349-0349.0904001.

Copyright: ( ) 2021 Authors. This is an open-access article distributed under the terms of the Creative Commons Attribution License, which permits unrestricted use, distribution, and reproduction in any medium, provided the original author and source are credited. 